\title{
Bazı Ekmeklik Buğday (Triticum aestivum L.) Çeşitlerinin Tane Verimi Stabilitesi ve Kalite Özelliklerinin Belirlenmesi
}

\author{
Bekir AKTAŞ ${ }^{1}$ \\ Hatice EREN ${ }^{2}$ \\ ${ }^{1}$ Tohumluk Tescil ve Sertifikasyon Merkez Müdürlüğü, Ankara \\ ${ }^{2}$ Bitkisel Üretim Genel Müdürlüğü, Ankara \\ Sorumlu yazar e-posta (Corresponding author e-mail):bekir_aktas@yahoo.com \\ Geliş Tarihi (Received): 05.11.2014 \\ Kabul Tarihi (Accepted): 09.12.2014 \\ Öz \\ Genotipler farklı çevre koşullarında farklı performans gösterebilmektedir. Ülkemizde serin iklim tahıllarında \\ tescil denemeleri bölgesel olarak yürütülmektedir. Ege Bölgesi ve Güney Marmara Bölgesi 2009 yılına kadar \\ ayrı bölgeler olarak değerlendirilirken bu yıldan itibaren birleştirilmiştir. Bu araştırmanın amacı; her iki bölge \\ için ayrı ayrı tescil ettirilmiş Ziyabey 98, Basri Bey 95, Gönen 98, Tahirova 2000, Pamukova 97 ve Hanlı \\ ekmeklik buğday çeşitlerinin tane verimi stabilitesi ile kalite özelliklerinin belirlenmesidir. Ayrıca bu çalışma; \\ bölgelerin birleştirilmesi konusunda günümüzde de farklı görüşlerin olması nedeniyle geçmişe dönük genel \\ bir değerlendirme yapılabilmesi açısından önem taşımaktadır. Denemeler tesadüf blokları deneme desenine \\ göre dört tekerrürlü olarak 2010-2013 yılları arasında yürütülmüştür. Stabilite parametresi olarak; ortalama \\ tane verimi, regresyon katsayısı (b), regresyon sabitesi (a), determinasyon katsayısı $\left(R^{2}\right)$ ve varyasyon \\ katsayısı (VK) kullanıımıştır. Bu stabilite parametreleri ele alındığında tane veriminde Ziyabey 98, Basri Bey \\ 95 ve Hanlı çeşitleri öne çıkmaktadır. Bin tane ağırlığı yönünden en yüksek değeri Tahirova 2000 gösterirken, \\ hektolitre ağırlığında çeşitler arasında istatistiki olarak önemlilik saptanmamıştır. Protein oranı, Zeleny \\ sedimentasyon ve alveograf enerji değerinde Pamukova 97 en yüksek değerleri gösteren çeşit olmuştur.
}

Anahtar Kelimeler: Ekmeklik buğday, tane verimi, stabilite parametreleri, kalite

\section{Determination of Quality Characteristics and Stability Analysis of Grain Yield of Some Bread Wheats (Triticum aestivum L.) Varieties}

\begin{abstract}
Genotypes may show different performance in different environmental conditions. Registration trials of cool season cereals are carried out in our country as a regional. Aegean and Southern Marmara regions were considered as separate regions until the year 2009. After that they are combined. The aim of this research was to determine the grain yield stability and quality characteristicsof Ziyabey 98, BasriBey 95, Gönen 98, Tahirova 2000, Pamukova 97 and Hanlı bread wheat varieties which were registered separately for both regions. Differences of opinion regarding the integration of the region continues today. Furthermore, this study; a general assessment is important in terms of retroactively be made. Experiments were established in randomized completely block design with four replicates between the years 2010-2013. Mean yield of varieties, regression coefficient (b), regression line intercept $(a)$, determination coefficient $\left(R^{2}\right)$ and coefficient variation $(\mathrm{CV})$ were evaluated as stability parameters. According to the result of stability parameters, Ziyabey 98, BasriBey 95 and Hanlı varieties came to the fore in grain yield. The highest value in a thousand kernel weight was obtained in Tahirova 2000. There was no statistical significance between varieties in hectoliter weight. Pamukova 97 was showed the highest value in terms of protein content, zeleny sedimentation and alveograf energy value.
\end{abstract}

Keywords: Bread wheat, grain yield, stability parameters, quality

\section{Giriş}

$\mathrm{s}$ erin iklim tahılları adaptasyon yetenekleri sayesinde geniş ekim alanı bulan türleri kapsamaktadır. Ülkemizin farklı ekolojik bölgelerden oluşması ıslahçıları bu bölgelere uygun genotipleri seçmeye yönlendirmektedir. Buna paralel olarak serin iklim tahıllarında çeşit

tescil denemeleri de bölgesel olarak yürütülmektedir. Her bölgenin iklim, toprak, hastalık ve zararlılarına göre çeşit ıslah çalışmalarında seleksiyon kriterleri değişmektedir. 
Genotiplerin değişen çevre koşullarında gösterdiği tepkiler farklı olabilmektedir. Varyans analizleri ile ortaya konmaya çalışılan genotip $\mathrm{x}$ çevre ilişkisinin istatistiki olarak önemli olduğu durumlarda genotiplerin farklı çevre şartlarına gösterdiği tepkinin incelenmesi amacıyla farklı istatistik parametreler geliştirilmiştir. Genotiplerin farklı çevrelerdeki performanslarının incelenmesinde kullanılan metotlardan birisi de regresyon katsayıdır. Regresyon katsayısının 1'e yakın olması, regresyondan sapmanın düşük olması, genotipin verim ortalamasının genel verim ortalamasından yüksek olması stabiliteyi arttıran parametrelerdir (Eberhart and Russel 1966). Francis and Kannenberg (1978) genotipin varyasyon katsayısının düşük olması, Smith (1982) pozitif regresyon sabitesine (a) sahip olması gerektiğini bildirmişlerdir. Orta Anadolu Bölgesinde 19 çevrede yapılan çalışmada Taner ve ark. (2004) kötü çevre şartlarında Gerek 79 çeşidinin, iyi çevre şartlarında 2 ve 3 no'lu hatların ön plana çıktığını belirtmişlerdir. Dönmez (2002) 25 ekmeklik buğday çeşidi ile yaptığı araştırmada Kate A-1, Yakar, Prostor, Türkmen ve Saroz-95 çeşitlerinin iyi çevrelere, Gerek-79, Aytın-98 ve Altay-2000'in kötü çevrelere, Demir-2000, Harmankaya-99, Kırkpınar-79 ve İkizce-96'nın ise orta çevrelere uygun çeşitler olduğunu bildirmiştir. Şahin ve ark. (2011) bazı ekmeklik buğday genotiplerinin tane verimi ile kalite özellikleri arasındaki ilişkileri ve stabilite yeteneklerini incelediği çalışmada; Tosunbey ve Karahan 99 çeşitlerinin öne çıktığını belirtmişlerdir.

Ekmeklik buğdayda tane verimi yanında kalite özellikleri de önemlidir. Üretici birim alan tane verimi yüksek çeşitleri tercih ederken, sanayici ise tüketici tercihleri doğrultusunda teknolojik özellikleri iyi ürünleri tercih etmektedir. Mevzuatlarda yapılan değişikle tescil komitelerinde ilgili sanayi sektörünün de temsil edilmesi sağlanmıştır. Tüm tarafların intiyaçlarına cevap verebilecek yüksek verimli ve kaliteli çeşitlerin geliştirilmesi amaçlanmaktadır. Ülkemizde özellikle iklim koşullarının kaliteyi olumsuz etkilediği yıllarda paçallarda kullanılmak üzere kalite değeri yüksek buğday ithalatı yapılabilmektedir. Ülkemizin farklı ekolojik bölgelerden oluşması kalite değerine göre yapılan paçallarda avantaj sağlamaktadır. Bazı bölgelerimiz yüksek verim potansiyeli ile öne çıkarken, bazı bölgelerimiz verimi göreceli olarak düşük ancak yüksek kaliteli ürünlerle öne çıkmaktadır.

$\mathrm{Bu}$ araştırmanın amacı; Ege ve Güney Marmara Bölgeleri için tescil edilmiş 6 ekmeklik buğday çeşidinin tane verimi stabilitesi ile kalite özelliklerinin belirlenmesidir. Çeşit tescil denemelerinde Ege Bölgesi ve Güney Marmara Bölgesi ayrı bölgeler olarak değerlendirilirken 2009-2010 ekim yılından itibaren Serin İklim Tahılları Teknik Talimatında yapılan değişiklikle birleştirilerek tek bölge olarak değerlendirilmeye başlanmıştır. Günümüzde bölgelerin birleştirilmesi konusundaki görüş ayrılıkları devam etmektedir. Bu çalışma; serin iklim tahılları teknik talimatlarında ileride yapılabilecek çalışmalara da yön verebilecektir.

\section{Materyal ve Yöntem}

Bu çalışma, 2010-2013 yılları arasında kuru koşullarda İzmir (Menemen, Selçuk), Adapazarı (Merkez, Pamukova), Denizli, Bursa (Karacabey), Manisa (Beydere), Aydın (Nazilli, Söke) ve Balıkesir (Bandırma) lokasyonlarında; tesadüf blokları deneme desenine göre 4 tekerrürlü olarak yürütülmüştür. Denemelerin ekimi $6.0 \mathrm{~m}^{2}$ büyüklüğündeki parsellere parsel mibzeri ile yapılmış ve parsel biçerdöveri ile hasat edilmiştir. Ekimde $6 \mathrm{~kg} / \mathrm{da}$ saf azot hesabıyla Diamonyum fosfat, sapa kalkma döneminde $8 \mathrm{~kg} / \mathrm{da}$ saf azot hesabıyla Amonyum nitrat gübresi verilmiştir.

Denemelerde; Mısır Araştırma İstasyonu'na ait Tahirova 2000, Hanlı, Pamukova 97 ile Ege Tarımsal Araştırma Enstitüsü'ne ait Basri Bey 95, Ziyabey 98, Gönen 98 çeşitleri kullanılmıştır. Denemelerin yürütüldüğü yıllar ve lokasyonlar Çizelge 1'de verilmiştir.

Çizelge 1. Denemelerin yürütüldüğü çevreler Table 1. Locations of carried out to researches

\begin{tabular}{cll}
\hline $\begin{array}{c}\text { Çevre } \\
\text { no }\end{array}$ & \multicolumn{1}{c}{$\begin{array}{c}\text { Deneme } \\
\text { yeri }\end{array}$} & Yetiştirme dönemi \\
\hline 1 & Menemen & $2010-2011$ \\
2 & Adapazarı & $2010-2011$ \\
3 & Pamukova & $2010-2011$ \\
4 & Denizli & $2010-2011$ \\
5 & Adapazarı & $2011-2012$ \\
6 & Pamukova & $2011-2012$ \\
7 & Karacabey & $2011-2012$ \\
8 & Menemen & $2011-2012$ \\
9 & Beydere & $2011-2012$ \\
10 & Nazilli & $2011-2012$ \\
11 & Selçuk & $2011-2012$ \\
12 & Adapazarı & $2012-2013$ \\
13 & Pamukova & $2012-2013$ \\
14 & Karacabey & $2012-2013$ \\
15 & Menemen & $2012-2013$ \\
16 & Söke & $2012-2013$ \\
17 & Denizli & $2012-2013$ \\
18 & Bandırma & $2012-2013$ \\
\hline
\end{tabular}


Verilerin istatistik analizi tesadüf blokları deneme desenine göre SAS istatistik analiz programı kullanılarak yapılmıştır. Lokasyonların yıllara dengeli dağılmaması nedeniyle her yer bir çevre olarak kabul edilmiş ve 18 farklı çevrede değerlendirmeler yapılmıştır. Genotip x çevre interaksiyonu önemli bulunmuş ve regresyon katsayısının 1'e eşit olduğu kabul edilerek stabilite analizi uygulanmıştır (Eberhart and Russel 1966). Stabilite parametresi olarak; ortalama tane verimi $(x)$, regresyon katsayısı (b), regresyon sabitesi (a), determinasyon katsayısı $\left(R^{2}\right)$ ve varyasyon katsayısı (VK) kullanılmıştır. Birim alan tane verimine ilişkin veriler 4 tekerrürlü olarak varyans analizine tabi tutulurken, kalite özelliklerinde tekrarlamalı veri olmadığı için varyans analizlerinde yerler ve yıllar tekerrür olarak kabul edilmiştir.

Her lokasyondan her bir çeşide ait $3 \mathrm{~kg}$ numune alınmış ve kalite analizleri bu numunelerde yapılmıştır. Bin tane ağırlığı numunelerden tesadüfi olarak $4 \times 100$ adet sayılarak tartılmış ve hesaplanarak kuru madde üzerinden verilmiştir. Hektolitre ağırlığı Uluöz (1965)'e göre yapılmıştır. Protein oranı ICC 105/2 metoduna göre yapılarak sonuçlar kuru madde üzerinden verilmiştir (Anonim 2002a). Zeleny sedimentasyon analizi ICC 116-1 yönteminde belirtilen işlemlere göre yapılmıştır (Anonim 2002b). Alveograf enerji değeri Anonim 2000'e göre yapılmıştır.

\section{Bulgular ve Tartışma}

\section{Tane verimi}

Varyans analiz sonuçlarına göre çeşitlerin birim alan tane verimleri arasındaki fark ve çeşitlerin birim alan tane verimleri üzerine çevrenin etkisi istatistiki olarak önemli bulunmuştur (Çizelge 2). En yüksek tane verimi ortalaması 2012-2013 ekim yılında Pamukova'da elde edilirken, en düşük tane verimi ortalaması yine aynı ekim yılında Bandırma lokasyonunda elde edilmiştir. Menemen lokasyonu tane verimi ortalaması bakımından 2012-2013 yılı Pamukova lokasyonunun ardından diğer iki yılda da en yüksek tane verimi ortalamasını göstermiştir. 2010-2011 ekim yılı Denizli, 20122013 ekim yılı Söke ve Bandırma lokasyonları $400 \mathrm{~kg} / \mathrm{da}$ 'ın altında verim ortalaması gösteren çevreler olmuştur (Çizelge 3). Deneme çevrelerinin birleştirilmiş ortalamalarına göre; Ziyabey 98 çeşidi $651.4 \mathrm{~kg} / \mathrm{da}$ ortalama tane verimi ile ilk sırada yer almıştır. Ziyabey 98 çeşidini aynı istatistiki grupta yer alan Hanlı ve Basri Bey 95 çeşitleri takip etmiştir. Gönen 98 ve Pamukova 97 çeşitleri tane verimi ortalamasında
Çizelge 2. Çeşitlerin birim alan tane verimine ilişkin birleştirilmiş varyans analizi

Table 2. The results of variance analysis belongs to grain yields per area of research materials

\begin{tabular}{lrrr}
\hline \multicolumn{1}{c}{ V.K } & \multicolumn{1}{c}{ S.D. } & \multicolumn{1}{c}{ K.O. } & \multicolumn{1}{c}{ F } \\
\hline Tekerrür (Çevre) & 54 & 10025.4 & $4.0^{* *}$ \\
Çevre & 17 & 580962.6 & $232.1^{* *}$ \\
Çeşit & 5 & 127275.2 & $50.9^{* *}$ \\
Çevre* Çeşit & 85 & 16012.8 & $6.4^{* *}$ \\
Hata & 270 & 2503.2 & \\
Genel & 431 & & \\
\hline
\end{tabular}

son sırada yer alan çeşitler olmuşlardır. Çeşitlerin tane verimleri ortalaması Islah edildikleri bölgeler esas alınarak incelendiğinde; Ziyabey 98 ve Basri Bey 95 çeşitlerinin Güney Marmara Bölgesindeki tane veriminin, Ege Bölgesindeki tane veriminden daha yüksek olduğu görülmektedir. Gönen 98 çeşidi kendi bölgesi olan Ege'de iyi verim değerine sahiptir. Güney Marmara Bölgesinde geliştirilmiş çeşitler olan Tahirova 2000, Pamukova 97 ve Hanlı'nın ise kendi bölgelerinde daha yüksek tane verimine ulaştığı belirlenmiştir (Şekil 1).

\section{Stabilite analizi}

Toplam 18 çevreden elde edilen verilere stabilite analizi uygulanmıştır. Elde edilen sonuçlar Çizelge 4'de verilmiştir. Çeşitlerin stabilite analizleri için farklı yöntemler geliştirilmiştir. Bunlardan birisi de çeşitlerin verimlerinin genel ortalama verim ve regresyon katsayılarının 1 ile karşılaştırılarak elde edilen parametrelerin grafik ile gösterilmesidir (Finlay and Wilkinson 1963, Eberhart and Russel 1966). Bu çalışmanın üzerine güven sınırları çizilerek çeşitlerin stabilitesinin yorumunun geliştirilmesi amaçlanmıştır (Şekil 2). Ayrıca regresyon katsayısı ile regresyon sabitesinin çevre ortalamalarına göre hesaplanan $(y=a+b x)$ beklenen verim değerleri Şekil 3'de verilmiştir.

Ziyabey 98, Hanlı ve Basri Bey 95 çeşitlerinin tane verimi genel ortalamanın üzerinde; Tahirova 2000, Pamukova 97 ve Gönen 98 çeşitlerinin tane verimleri ise genel ortalamanın altında kalmıştır (Çizelge 4). Pamukova 97, Basri Bey 95 ve Ziyabey 98 çeşitlerinin b değerinin 1'in üzerinde; Hanlı, Tahirova 2000 ve Gönen 98 çeşitlerinin b değerinin ise 1'in altında kaldığı belirlenmiştir (Çizelge 4). Gönen 98'in tane veriminin genel ortalamanın çok altında kalması ve düşük $b$ değeri ile kötü çevre koşullarına kötü uyum gösteren bölgede, diğerlerinin ise tüm bölgelere orta uyum gösteren bölgede olduğu saptanmıştır (Şekil 2). Her ne kadar diğer çeşitler tüm bölgelere orta 
Çizelge 3. Denemelenre yer alan çeşitlerin yıllara ve kokasyonlara ilişkin ortalama tane verimleri (kg/da). Table 3. Average grain yields of research materials in different years and locations $(\mathrm{kg} / \mathrm{da})$

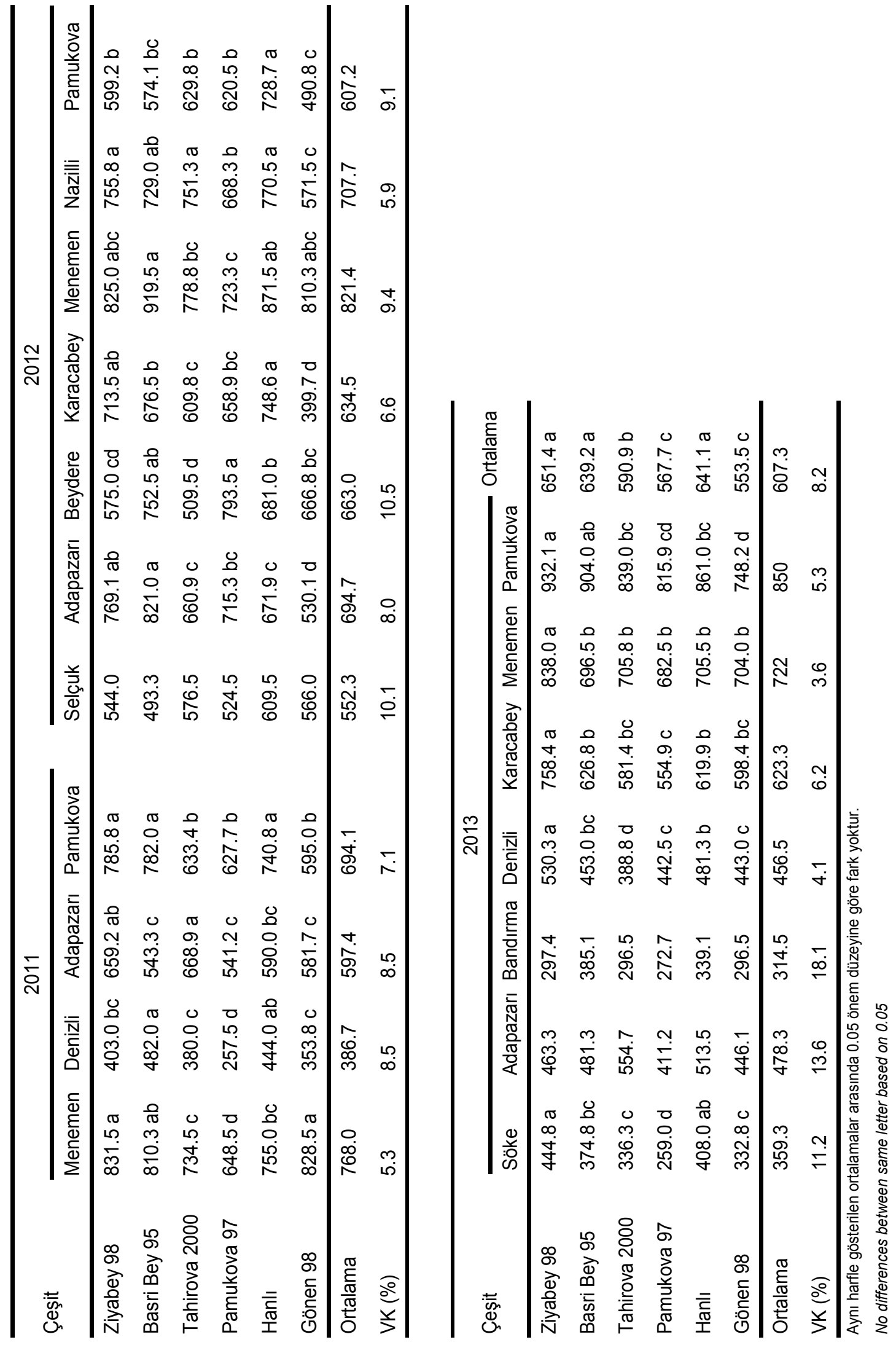


uyum göstermiş olsalar da, aralarında uyum yönünden farklılıklar bulunmaktadır. Bu nedenle stabilite analizinde regresyon sabitesi (a), determinasyon katsayısı $\left(R^{2}\right)$, değişim katsayısı (VK) gibi başka parametreler kullanarak bu farklıı̆ı̆ belirlenmesine gidilmiştir.

Ziyabey 98 ve Basri Bey 95 çeşitlerinin stabilite parametreleri birbirine yakın değerler vermiştir. Tane verimleri genel ortalamanın üzerinde, b değerleri 1'in biraz üzerinde, negatif düşük a değerleri, determinasyon katsayısı ve değişim katsayılarının benzer olması ile çalışılan çeşitler arasında stabilitesi iyi olan çeşitler olduğu belirlenmiştir. Her iki çeşit de kötü ve iyi çevre koşullarında yüksek tane verimi ile dikkati çekmektedir. a değerinin negatif olması çeşitlerin iyi çevre koşulları istediğinin göstergesi olmakla birlikte Ziyabey 98 ve Basri Bey 95 çeşitlerinin $a$ değerlerinin küçük ve $b$ değerlerinin 1'in biraz üzerinde olması çeşitlerin kötü çevrelerde de verimlerinde anlamlı bir düşme olmadığını göstermektedir.

Hanlı çeşidinin tane verimi genel ortalamanın üzerindedir. Determinasyon katsayısı Ziyabey 98 ve Basri Bey 95 çeşitleri ile aynıdır. b değeri
1 'in altında, değişim katsayısı düşük ve pozitif yüksek a değerine sahiptir. Denemede yer alan çeşitler içerisinde Hanlı çeşidi pozitif ve yüksek a değeri ile dikkati çekmektedir. Bu sonuçlara göre; Hanlı çeşidinin kötü çevre koşullarında Ziyabey 98 ve Basri Bey 95 çeşitlerinden daha yüksek verime sahip olduğu çevre koşulları iyileştikçe bu performansını koruyamadığı ve veriminin bu iki çeşidin altında kaldığını göstermektedir.

Tahirova 2000, Pamukova 97 ve Gönen 98 çeşitlerinin tane verimleri genel ortalama verimin altındadır. Tahirova 2000 ve Gönen 98 çeşitlerinin b değeri 1'in altında, determinasyon katsayıları düşük ve değişim katsayıları yüksektir. Tahirova 2000 çeşidinin pozitif ve Gönen 98 çeşidine göre daha yüksek a değerine sahip olması nedeni ile her iki çevre koşulunda da Gönen 98 çeşidinden daha yüksek verime sahip olduğu saptanmıştır. Gönen 98 çeşidi kötü koşullarda Pamukova 97 çeşidi dışında diğer çeşitlerden daha düşük verime sahip olduğu çevre koşulları iyileştikçe verimindeki artışın diğer çeşitler kadar olmadığı ve iyi çevre koşullarında çalışılan çeşitler içerisinde en düşük verime sahip olduğu belirlenmiştir.

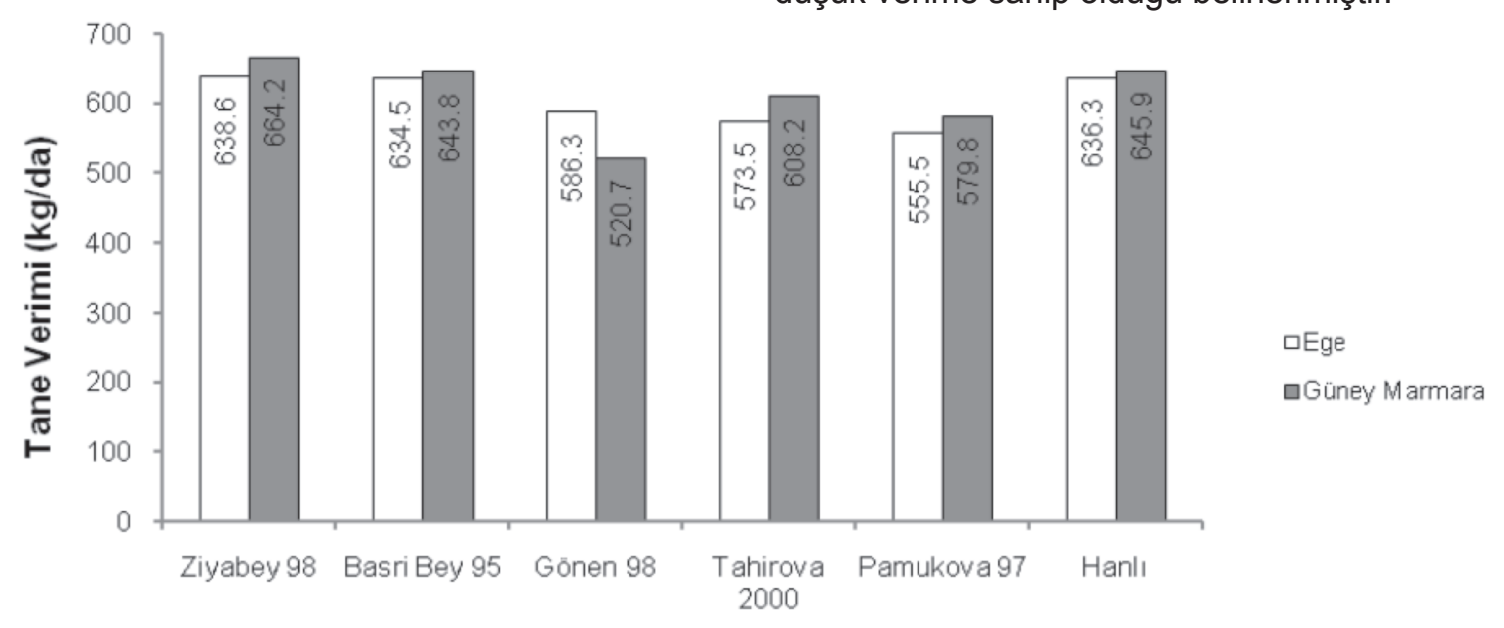

\section{Çeşitler}

Şekil 1. Çeşitlerin Ege ve Güney Marmara Bölgesindeki tane verimi ortalamaları

Figure 1. Average grain yields of research materials in Ageans and Southern Marmara

Çizelge 4. Bazı stabilite parametrelerine ilişkin değerler

Table 4. Some values of the stability parameters

\begin{tabular}{lccccc}
\hline Çeşitler & $\mathrm{x}$ & $\mathrm{b}$ & $\mathrm{a}$ & $\mathrm{R}^{2}$ & $\mathrm{VK}$ \\
\hline Ziyabey 98 & 651.4 & 1.08 & -5.8 & 0.81 & 12.2 \\
Basri Bey 95 & 639.2 & 1.06 & -2.6 & 0.82 & 11.8 \\
Tahirova 2000 & 590.9 & 0.95 & 16.1 & 0.77 & 13.5 \\
Pamukova 97 & 567.7 & 1.06 & -75.5 & 0.81 & 14.0 \\
Hanlı & 641.1 & 0.95 & 65.4 & 0.82 & 10.7 \\
Gönen 98 & 553.5 & 0.91 & 2.3 & 0.74 & 14.9 \\
\hline
\end{tabular}




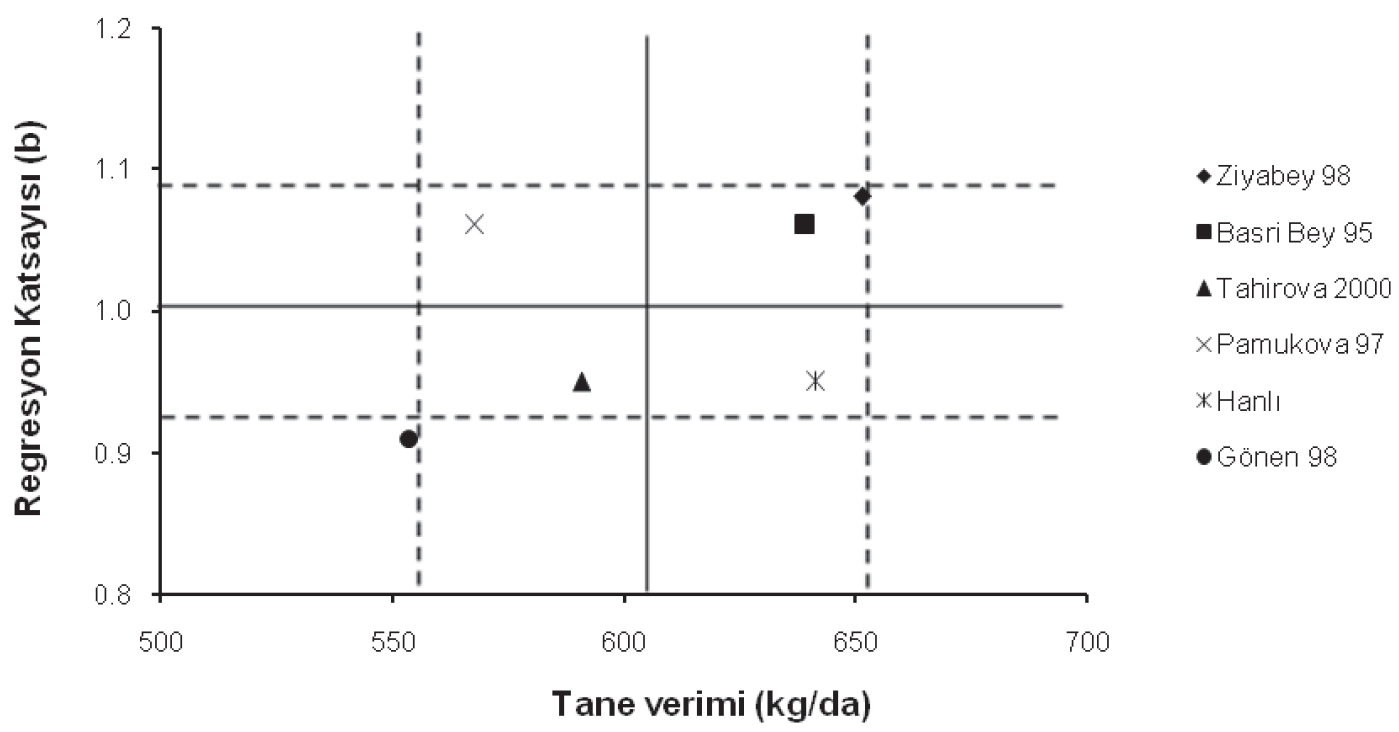

Şekil 2. Çeşitlerin ortalama tane verimi ve regresyon katsayılarına göre dağılımı

Figure 2. Average grain yields and distribution of regression coefficient of research materials

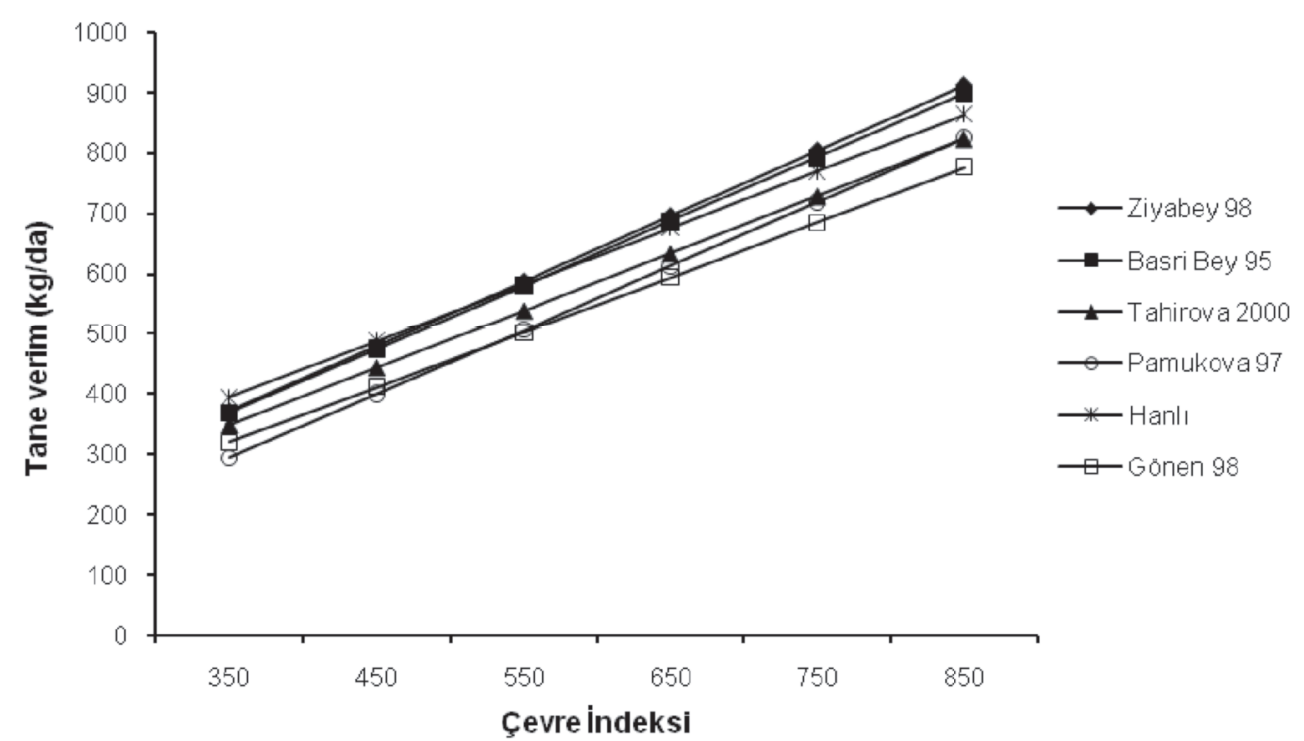

Şekil 3. Regresyon grafiği

Figure 3. Regression graph

Pamukova 97 çeşidinin ise $b$ değeri 1 'in üzerinde, yüksek negatif a değeri, determinasyon katsayısı Ziyabey 98 ve Basri Bey 95 çeşitleri ile aynı, varyasyon katsayısı ise yüksektir. Denemede yer alan çeşitler içerisinde yüksek negatif a değeri ile dikkat çekmektedir. Bu sonuçlara göre; kötü çevre koşullarında çalışılan çeşitler içerisinde en düşük verime sahipken, çevre koşulları iyileştikçe verimini artırdığı belirlenmiştir.

\section{Kalite kriterleri}

Denemede yer alan çeşitlerin bazı kalite özellikleri Çizelge 5'de verilmiştir. Pamukova 97 ve Hanlı çeşitlerinin tane renkleri kırmızı, diğer çeşitlerin ise beyazdır. Çeşitlerin hektolitre ağırıkları ortalamaları yönünden istatistiki farklılık saptanmamış olup diğer özellikler yönünden ise çeşitlerin ortalamaları arasındaki fark önemli bulunmuştur. 

Wheats (Triticum aestivum L.) Varieties"

Çizelge 5. Çeşitlerin kalite özelliklerine ilişkin ortalama değerler ve farklılık gruplandırmaları Table 5. Average of some quality characteristics and variation grouping of research varieties

\begin{tabular}{lcrcccc}
\hline \multicolumn{1}{c}{ Çeşitler } & $\begin{array}{c}\text { Tane } \\
\text { rengi }\end{array}$ & $\begin{array}{c}\text { Bin tane } \\
\text { ağırlığı (g) }\end{array}$ & $\begin{array}{c}\text { Hektolitre } \\
\text { ağırlığı } \\
\mathbf{( k g / h l )}\end{array}$ & $\begin{array}{c}\text { Protein } \\
\mathbf{( \% )}\end{array}$ & $\begin{array}{c}\text { Zeleny } \\
\text { Sedimentasyon } \\
(\mathbf{m l})\end{array}$ & $\begin{array}{c}\text { Alveograf } \\
\text { Enerji Değeri } \\
(\mathbf{J})\end{array}$ \\
\hline Basri Bey 95 & Beyaz & $32.9 \mathrm{~d}$ & 78.6 & $13.68 \mathrm{c}$ & $30.4 \mathrm{c}$ & $139.3 \mathrm{~cd}$ \\
Gönen 98 & Beyaz & $35.3 \mathrm{c}$ & 78.9 & $13.79 \mathrm{c}$ & $40.7 \mathrm{~b}$ & $202.3 \mathrm{~b}$ \\
Hanlı & Kırmızı & $35.8 \mathrm{bc}$ & 79.4 & $13.65 \mathrm{c}$ & $43.0 \mathrm{~b}$ & $198.4 \mathrm{~b}$ \\
Pamukova 97 & Kırmızı & $31.3 \mathrm{e}$ & 79.1 & $15.91 \mathrm{a}$ & $53.5 \mathrm{a}$ & $267.9 \mathrm{a}$ \\
Tahirova 2000 & Beyaz & $38.2 \mathrm{a}$ & 79.4 & $14.67 \mathrm{~b}$ & $30.6 \mathrm{c}$ & $159.9 \mathrm{c}$ \\
Ziyabey 98 & Beyaz & $35.9 \mathrm{ab}$ & 78.7 & $13.73 \mathrm{c}$ & $32.6 \mathrm{c}$ & $123.1 \mathrm{~d}$ \\
\hline Ortalama & & 35.1 & 79.0 & 14.2 & 38.5 & 182.5 \\
F & & $* *$ & Ö.D. & $* *$ & $* *$ & $* *$ \\
VK & & 5.3 & 1.2 & 4.2 & 12.1 & 21.8 \\
\hline
\end{tabular}

Aynı harflerle gösterilen ortalamalar arasında 0.05 düzeyinde fark yoktur.

No differences between same letter based on 0.05

Bin tane ağırlığı ve hektolitre ağırlığı buğdayda kaliteyi belirleyen önemli fiziksel özelliklerdir (Demir ve ark. 1999). En yüksek 1000 tane ağırı̆̆ı Tahirova 2000 çeşidinden (38.2 g), en düşük 1000 tane ağırlığı Pamukova 97 (31.3 g) çeşidinden elde edilmiştir. Çevre koşulları ve yetiştirme tekniği uygulamaları buğdayın tanesindeki protein oranını etkileyen önemli faktörlerdir (Bushuk and Zillman 1978). Protein oranı yönünden çeşitler üç istatistiki grupta yer almıştır. Tanedeki en yüksek protein oranını Pamukova 97 (\%15.91) çeşidi, en düşük protein oranını ise Hanlı (\%13.65) çeşidi göstermiştir.

Sedimantasyon değeri buğdayın protein kalitesini gösteren en önemli kriterlerden biridir (Peterson et al. 1992). En yüksek Zeleny sedimentasyon değeri Pamukova 97 çeşidinden $(53.5 \mathrm{ml})$ elde edilirken, en düşük Zeleny sedimentasyon değeri Basri Bey 95 çeşidinden (30.4 ml) elde edilmiştir. Reolojik analizlerden alveograf analizinin en önemli parametresi olan enerji değeri ekmeklik buğdayda önemli bir kalite kriteridir (Keçeli 2012). Pamukova 97 çeşidi $267.9 \mathrm{~J}$ alveograf enerji değeri ile ilk sırada yer almıştır. Bunu Gönen 98 (202.3 J) ve Hanlı (198.4 J) çeşitleri takip etmiştir.

Tüm çalışılan kalite parametreleri ile çeşitler birlikte değerlendirildiğinde; kırmızı taneli Pamukova 97 çeşidinin 1000 tane ağırlığının düşük olduğu ancak tanedeki protein oranı, Zeleny sedimentasyon ve alveograf enerji değerinin denemede yer alan diğer çeşitlerden yüksek olduğu belirlenmiştir. Bu değerler ile denemedeki en kaliteli çeşit olduğu sonucuna varılmıştır.

\section{Sonuç}

Ege ve Güney Marmara Bölgesinin birlikte değerlendirildiği bu çalışmada her iki bölgede faaliyet gösteren araştırma enstitülerinin geliştirdiği çeşitler kullanılmıştır. Bu çeşitler arasında incelenen özellikler yönünden çok büyük kopmalar gözlenmediği saptanmıştır. Hatta Ege Bölgesi orijinli Ziyabey 98 ve Basri Bey 95 çeşitleri kendi bölgeleri dışında daha yüksek tane verimi değerine ulaşmıştır. Güney Marmara Bölgesi orijinli 3 çeşit ise kendi bölgelerinde daha yüksek tane verimi değeri göstermiş̧ir.

İncelenen stabilite parametreleri bakımından Ziyabey 98, Hanlı ve Basri Bey 95 çeşitleri öne çıkmıştır. Pamukova 97 çeşidi kalite kriterlerinde bin tane ağırlığı dışında yüksek değerler göstermiştir.

\section{Kaynaklar}

Anonim, 2000. American Association of Cereal Chemists. A.A.C.C. Method 54-30A

Anonim, 2002a. Determination of Crude Protein in Cereals and Cereal Products for Food and Feed. International Association for Cereal Science and Technology (ICC) Standard No:105/2.

Anonim, 2002b.Standard Methods of International Association for Cereal Science and Technology (ICC). Vienna, Austria

Bushuk W. and Zillman R.R., 1978. Wheat Cultivar Identification by Gliadin Electrophoregrams, I. Apparatus, Method Nomencleature. Canadian Journal of Plant Sci. 58:505-515. 
Demir İ., Yüce S., Budak N., Tosun M., Turgut I. ve Konak C., 1999. Ekmeklik Buğday Genotiplerinin Verim Performanslarının Rank (Sıra) Analizi ile İncelenmesi. Türkiye 3. Tarla Bitkileri Kongresi, Cilt 1, sf. 58-63, 15-18 Kasım, Adana

Dönmez E., 2002. Bazı ekmeklik buğday (Triticum aestivum L.) çeşitlerinde genotip $x$ çevre interaksiyonları ve stabilite analizleri üzerine bir araştırma. Doktora tezi, Gaziosmanpaşa Üniversitesi Fen Bilimleri Enstitüsü (Basılmamış), Tokat

Eberhart S.A. and Russell W.A., 1966. Stability parameters for comparing varieties. Crop. Sci., 6:36-40.

Francis T. R. and Kannenberg L. W., 1978. Yield stability studies in short season maize. Can. J. Plant Sci. 58: 1029-1034.

Finlay K.W. and Wilkinson G.N., 1963. The analysis of adaptation in a plant breeding programme. Aust. J. Agric. Res., 14:742-754.

Keçeli, A., 2012. Kuru Koşullarda Bazı Ekmeklik Buğday (Triticum aestivum L.) Çeşitlerinde Farkı Ön Bitkilerin Verim ve Kalite Özellikleri Üzerine Etkisi. Doktora tezi, Ankara Üniversitesi Fen Bilimleri Enstitüsü (Basılmamış), Ankara
Peterson C.J., Graybosch R.A., Baenziger P.S. and Grombacher A.W., 1992. Genotype and environment effects on quality characteristics of hard red winter wheat. Crop Sci. 32: 98103.

Smith E. L., 1982. Heat and drought tolerant wheats of the future. In: Proc. Natl. Wheat Res. Conf., Betswille, M.D. 26-28 Oct. National Association of Wheat Growers Foundation Washington, DC.

Şahin M., Akçacık A. ve Aydoğan S., 2011. Bazı ekmeklik buğday genotiplerinin tane verimi ile kalite özellikleri arasındaki ilişkiler ve stabilite yetenekleri. Anadolu, J. of AARI 21(2) 2011:39-48.

Taner S., Çeri S., Kaya Y., Akçura M., Ayrancı R. ve Özer E., 2004. Bazı ekmeklik buğday (T. aestivum L.) genotiplerinin Orta Anadolu Bölgesi kuru koşullarında dane verimi stabilitesi. Bahri Dağdaş U.T.A.E. Bitkisel Araştırma Dergisi, 2:21-26.

Uluöz M., 1965. Buğday, un ve ekmek analiz metodları. E.Ü.Ziraat Fakültesi. Yayınları No: 57. E.Ü.Matbaası, Bornova. 